\title{
Assessment of Food Hygienic and Vending Practices among Street Food Vendors in Buea and Kumba City Council (South-West Region Cameroon)
}

\author{
Kaptso $\mathrm{KG}^{1,2 *}$, Tchabo $\mathrm{W}^{3,4}$, Chebelem Mbafor $\mathrm{B}^{1}$, Asoba $\mathrm{NG}^{1}$, Amungwa $\mathrm{AF}^{1}$ \\ and Mbofung $\mathrm{CMF}^{3,5}$ \\ ${ }^{1}$ Department of Social Economy and Family Management, Higher Technical Teachers' Training \\ College, University of Buea, Kumba, South West Region, Cameroon \\ ${ }^{2}$ Department of Chemical Engineering, School of Chemical Engineering and Mineral Industries, \\ University of Ngaoundere, Ngaoundere, Cameroon
}

Research Article

Volume 6 Issue 2

Received Date: March 10, 2021

Published Date: March 25, 2021

DOI: $10.23880 /$ fsnt- 16000263

${ }^{3}$ Department of Food Sciences and Nutrition, ENSAI, University of Ngaoundere, Ngaoundere,

\section{Cameroon}

${ }^{4}$ School of Food and Biological Engineering, Jiangsu University, 301 Xuefu Road, Zhenjiang 212013, People's Republic of China ${ }^{5}$ Department of Food Science and Technology, College of Technology, University of Bamenda, Bambili, North West Region, Cameroon

*Corresponding author: Kaptso KG, Department of Chemical Engineering, School of Chemical Engineering and Mineral Industries, University of Ngaoundere, Ngaoundere, Cameroon, Tel: +237 699220 415; Email: kaptso@yahoo.fr

\section{Abstract}

Street food vending is one of the major activities in the large informal food sector of most developing countries especially in urban centers. It has become an omnipresent activity especially influenced by urbanization and globalization. Street foods play an important role in meeting the food demands of urban duellers, especially the urban poor though their hygiene is very doubtful. While this development is positive in many ways, it also presents new public health challenges for the urban population. This work aimed to evaluate the basic characteristics of street food services and hygienic condition of the processing and distribution of street food. A cross sectional study approach was adopted focusing on some vending sectors in Buea and Kumba. Random samplings of 80 vendors were used and questionnaires were administered to vendors. The results showed that women dominate street food vending amongst all age groups. Most of street vendors have a low educational level and do not have any formal food safety training which contributed to the unsafe conditions under which the foods were prepared and vended. There were several poor personal hygienic practices amongst the vendors. Only $28.8 \%$ always used aprons; 22.5 $\%$ always covered their hair and $18.8 \%$ always kept away from food preparation and vending when sick or having a wound. Street foods are good sources of diseases as the government pays in less attention to the sector. The study recommends the creation of food centers, regulation of vending activities by the government and development of training programs to enrich vendors on food safety and hygiene.

Keywords: Street Food; Food Safety; Hygiene; Vending 


\section{Food Science \& Nutrition Technology}

\section{Introduction}

Street food originated in Greece, China and Rome and refers to food available in a public place, such as from a vendor on a street $[1,2]$. Street-vended foods are also defined as foods and beverages prepared and/or sold by vendors in streets and other public places for immediate consumption or consumption at a later time without further processing or preparation $[3,4]$. The street food sector plays an important role in the cities and towns of many developing countries in meeting the food demands of the urban and rural dwellers as such have therefore become an integral part of urban life [5]. It feeds millions of people daily with a wide variety of foods that are relatively cheap and easily accessible and are consumed with regularity and consistency across all income groups, but particularly among the urban poor [1,6-8]. Street vended foods are not only appreciated for their unique flavors, convenience and the role which they play in the cultural and social heritage of societies, they have also become important and essential for maintaining the nutritional status of the populations [9]. Food and Agriculture Organization records show that about 2.5 billion people worldwide eat street food every day [2]. Poor national economic performance, unemployment and poverty have increase street food vending activities in Africa [10]. This is the case of Cameroon where there have been noticeable increases of food vendors, although they are not regulated or monitored in terms of what they prepare and how they do it [11]. Quality and safety are two common concerns often cited with regard to street foods and they have been declared a major public health concern by international health agencies as many studies have shown association with microbiological contamination and low hygienic standards [12]. According to FAO millions of people fall ill, suffer complications or even die as a result of eating unsafe food [2]. In Cameroon, street foods create employment, generate income, and acts as a food energy-support instrument to the urban poor [11]. However its hygiene is very doubtful. Analysis showed the incidence of foecal-oral parasites among street vendors in Buea, with $56.7 \%$ being infected [13]. If they do not observe good hygienic food handling, then vending would become a potential channel for the transmission of food borne diseases as majority of disease outbreaks related to street foods were linked to negligence of food handlers [14]. Many countries do not regulate street food vendors and it is therefore possible to enter into street food vending with a relatively low startup cost, making this activity attractive to many low income urban residents. Nevertheless, much of the bias against street foods is based more on prejudice than empirical data as Official and reliable data on the street food trade and practices are largely lacking especially in developing countries $[15,16]$. Street foods are perceived to be a major public health risk due to lack of basic infrastructure and services, difficulty in controlling the large numbers of street food vending operations because of their diversity, mobility and temporary nature $[17,18]$. Very little is known about street food consumption in many Africa countries despite the fact that the sector plays a large role in national economy in terms of employment and sales of food [19]. There are even prospects that street foods will hold a bigger share of the food market in the future. Although studies on the hygiene and safety of street foods have been carried out in several developing countries, not much has been done in SouthWest Region of Cameroon especially in the cities of Buea and Kumba. It is on the basis of these prevailing circumstances that it becomes necessary to examine the hygienic and vending practices of street food by consumers in Buea and Kumba. In addition, the regulation of this informal sector, in terms of practice, policy and access to resources, is crucially lacking in Cameroon [11]. Therefore, the main objective of this study is to evaluate the hygienic and vending practices of street food in Buea and Kumba.

\section{Materials and Methods}

\section{Study Area}

Buea, one of the areas chosen for this study is one of the fastest growing of the six sub-divisions in Fako Division of the South west Region of Cameroon especially with the advent of the University of Buea in 1993 [20]. The town is located $15 \mathrm{Km}$ away from the seashore, and $60 \mathrm{Km}$ away from Douala, the economic capital of Cameroon. Kumba, also called K-town is the largest city in the South West region and the head quarter of Meme Division with an estimated population of about 400,000 inhabitants. It is elevated 240 $\mathrm{m}(790 \mathrm{ft}$ ) above sea level. Kumba is the terminus of a branch railway of the western system of Camrail. Kumba is the main commercial town in South-west Cameroon producing cocoa, palm oil, and timber. Trading in Kumba has attracted the interest of foreigners mostly Nigerians who control a greater percentage of Kumba main market.

\section{Study Design}

A cross-sectional descriptive study was conducted to analyse the street food conditions. For the purpose of this investigation a mobile food street cart was defined as a foodvending unit that is brought on wheels to a standard location. The study involved four separate zones in the municipality of Buea (Molyko, Buea town, Mile 17 and Muea) and three zones in Kumba (Buea road, Fiango and Three corners). About 50 percent of the total number of vendors that make up this zone participated in the study. These areas are also well-known for a high density of food vendors and cuts across all the representative groups involving the indigenous population, farmers, students, workers, public transporters, the rich and poor. 


\section{Food Science \& Nutrition Technology}

\section{Data collection and analysis}

The study used both quantitative and qualitative data collection techniques, including questionnaires, direct participant observations and documentary reviews so as to triangulate the evidence. Primary data was collected by the use of pre-tested questionnaires. A total of 80 questionnaires were administered, $62.5 \%$ in Kumba and $37.5 \%$ in Buea since the former has a higher population density and number of vendors than the later. The following inclusion criteria were considered: a) the food must be ready for consumption and sold on public streets and b) the carts must be structurally mobile, but must be located in standard, consistent locations. The interview was conducted in person to support more accuracy and completeness of the questionnaire. The instruments were developed based on international technical documents and national legislation on good practice and hygiene requirements for food [21,22]. The questionnaire was pre-tested on 10 food vendors and 7 consumers and necessary corrections made. Personal and environmental hygiene statuses were considered. This involved questions on their level of education, economic background, health habits and source of drinking water. Their hygienic practices in food processing and vending were also considered especially their sources of raw material, cooking methods, serving method and preservation of leftover food. The questionnaires were administered at the respondents' vending sites where the opportunity was used to start discussions with vendors.

Purposely and systematically observations were made on the activities at the vending sites to confirm the findings of the questionnaires. Particularly issues patterning to cleanliness, hygiene of vendors, food preparation and handling as well as ways in which the food was served to the clients. Observation was done at different times of the day so as to get a variety of street vendors since they mostly sell at different hours of the day but most especially from noon when most people are hungry and away from home.

\section{Statistical Analysis}

Data collected was recorded using Microsoft Excel and statistical analysis was done using Statistical Package for Social Sciences (SPSS) Version 20.

\section{Results and Discussion}

\section{Demographic Characteristics of Population}

The results reveal that more females $(73.8 \%)$ were involved in street food vending in both towns with only $26.2 \%$ being males (Table 1). Like Tinker and also Sher rightly put it, food preparation is cultural issue and in a typical african society its considered an activity for women $[23,24]$. Most women like the business since alongside their activities they equally provide food for their families thereby supporting their husbands. The findings of the present study indicate great domination of women in this venture, which agrees with the findings of previous studies [25]. This is in line with FAO as well as several studies that show that females dominate the street food sector [26-30]. Nevertheless, studies in Guwahati, India showed that majority of the vendors were male [31].

\begin{tabular}{|c|c|c|c|c|}
\hline \multicolumn{2}{|c|}{ Characteristics } & Frequency & Percentage & $\begin{array}{c}\text { Cumulative } \\
\text { Percentage }\end{array}$ \\
\hline \multirow{2}{*}{ Gender } & Male & 21 & 26.2 & 26.25 \\
\cline { 2 - 5 } & Female & 59 & 73.8 & 100 \\
\hline \multirow{2}{*}{ Location } & Buea & 30 & 37.5 & 37.5 \\
\cline { 2 - 5 } & Kumba & 50 & 62.5 & 100 \\
\hline
\end{tabular}

Table 1: Distribution of vendors by gender and location.

According to the results (Figure 1) female vendors dominate the street food sector amongst all age groups. Out of the 80 vendors sampled, most vendors (32) are of the age group 20-30 and closely followed by those in the age group 31-40 representing 27 of the sampled vendors. These age groups form the economically active population and their participation in street food trade reflects the high unemployment levels in the country. This supports findings that food vending, though illegal has helped to reduce unemployment and enhance livelihoods of most urban households especially when denied access to formal jobs $[14,19,32]$. There were fewer vendors below 20 years $(8.75 \%)$ and above 50 years $(7.5 \%)$ of age.

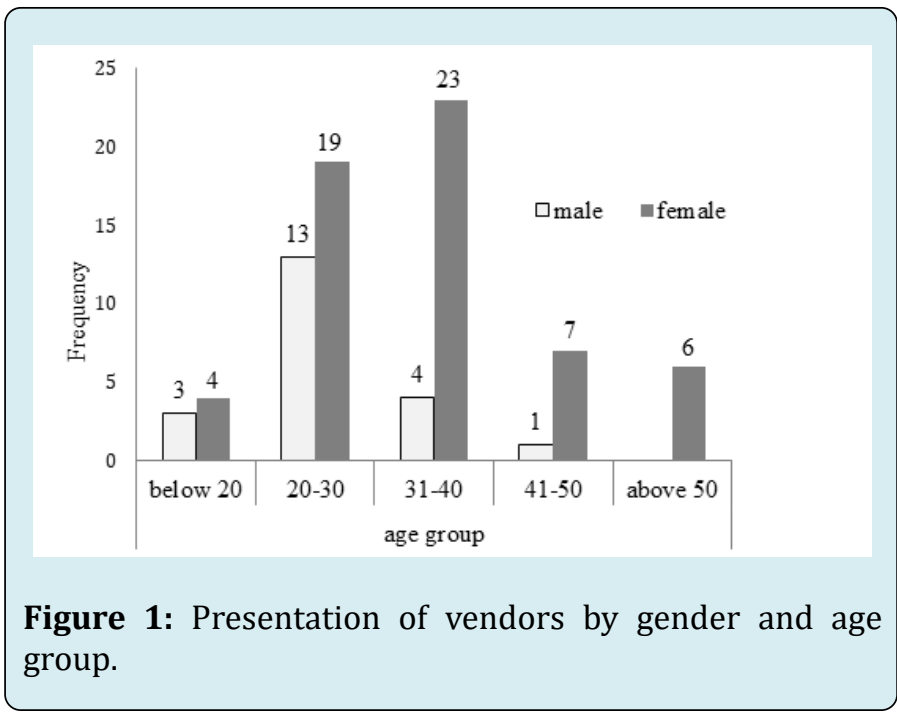

The studies reveal a low educational profile Figure 2 of vendors, as the peak prevalence in educational level is 
secondary school (32.5\%) while $28.8 \%$ of those surveyed had merely attained primary school. This suggests a low intellectual training of these street food vendors including social skills and personal hygiene imparted by formal educational training. The low educational level of the vendors is not only the case in Cameroon but also revealed by a series of related studies in Africa $[7,33]$. Rheinländer, et al. found in Ghana that educational level seemed to influence vendors' level of knowledge of food safety to some extent [34]. Vendors with formal hygiene education expressed more exact and elaborate hygiene knowledge, such as knowing the pathways of bacteria from fecal material to food, compared to vendors without any formal hygiene education.

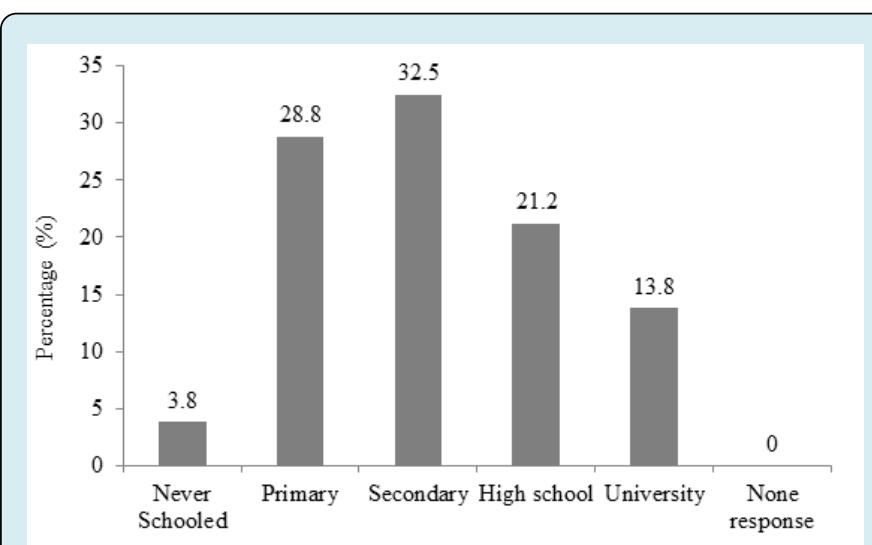

Figure 2: Distribution of vendors by level of education.

\section{Characteristics of Street Food Services}

In terms of ownership, 75\% of the street food businesses were self-owned (Figure 3 ) while $22.5 \%$ of the vendors were the owner's children or relatives. Only $1.2 \%$ of respondents was on voluntary service while $1.2 \%$ did not reveal their ownership or position in the business. This reveals that the street food business is a potential source of self-employment and a home based business as it mainly involves members of the family. From Figure 4 we see that most of those who go into street food vending as way of earning a living (52.5\%) while many others get into it because of the low investment required $(22.5 \%)$ and due to unemployment $(16.5 \%)$. A few other vendors were motivated by the fact that official training is not required to start such a business $(7.5 \%)$ while others specify that they got into street food vending because they dropped out of school because of lack of money to continue their education. This results show that most vendors see food vending as a way of earning a living in the midst of high unemployment rates in the country and are also motivated by the low investment capital required. This is in tandem with reports that unemployment and poverty has increase street food vending activities in Africa [10].

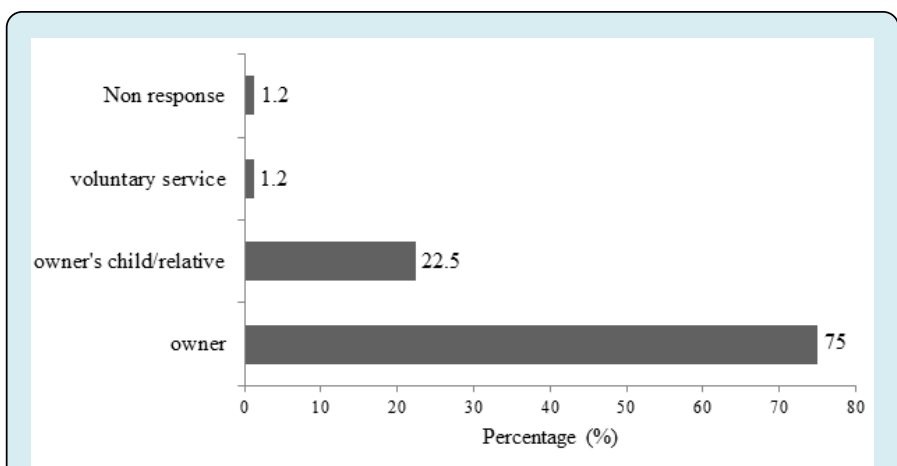

Figure 3: Distribution of vendors by ownership.

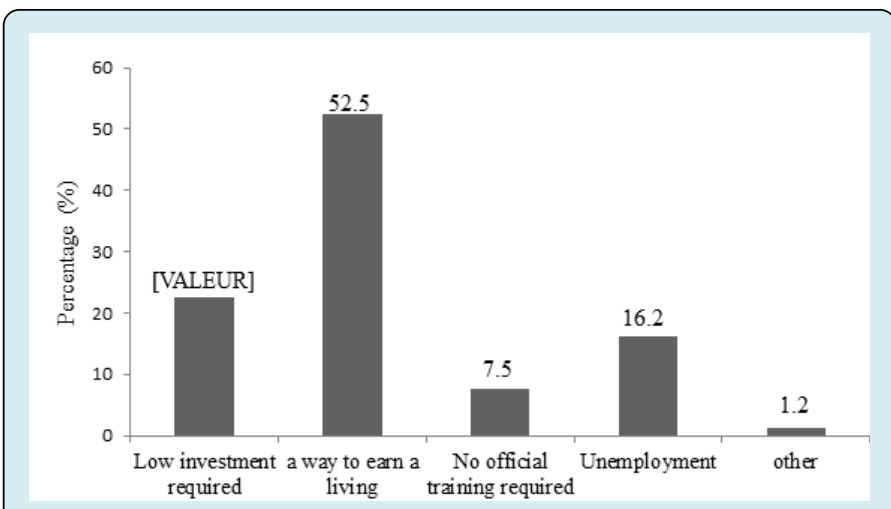

Figure 4: Reasons for engagement in the street food vending.

Interestingly, the start-up capital for street food business is very minimal (Figure 5) as most of the vendors (40\%) started up with 20,000-40,000 FCFA, $21.2 \%$ used 41,00060,000 FCFA while $18.8 \%$ started up with capital even less than 20,000 FCFA. This means that with a maximum capital of 60,000 FCFA, $80 \%$ of the vendors were able to set up their businesses. This amount is very low compared to other capital intensive businesses in these localities. The low capital requirement reflects little money spent on setting up vending units since they are mainly crude structures by the road side. This confirms results of research by Fellows and Hilmi that many people get into the street food business due to low investment capital [35]. Figure 6 shows that most (53.8\%) of the sampled vendors obtained their starting capital from personal savings. $26.2 \%$ obtained support from family members to start their businesses and $13.8 \%$ got their capital from tontine (njangi) houses. Most vendors therefore get their starting Capital from personal savings and support from family members $(80.6 \%)$. This means that one could conveniently save little amount of money to get into street food vending and does not necessarily needs to go to a bank and other financial houses to get a loan. This findings match with FAO that street food vending requires small amounts of capital and merely basic facilities to start up with [2]. Unlike in other research were average earnings of a of vendor were 
four times more than the minimum wage and are often times comparable to the wages of skilled laborers employed in the formal sector [28]. Vendors complained of low profit margins (Figure 7) as most vendors (58.8\%) consider the vending activity to be unrewarding as they are unable to make profits of up to 50.000 F.CFA slightly above the minimum wage level of the country. This contradicts previous research in Cameroon that vendors can make profits several times higher than the minimum wage of the country [30]. They however love their business as most of their families are able to feed on part of the food they sell especially leftover food. Employment of others in street food trade is not guaranteed (Figure 8 ) as $80 \%$ of the vendors declare out rightly that they do not employ anyone while $11 \%$ employs just a single person. Most vendors are the business owners themselves while support comes mainly from their relatives confirming that street food vending is predominantly a family based activity, with very few vendors paying any other employees [36]. Nevertheless the activity has gone a long way to reduce unemployment levels in the country right at the family level and has become a major way by which most women support their husbands and families.
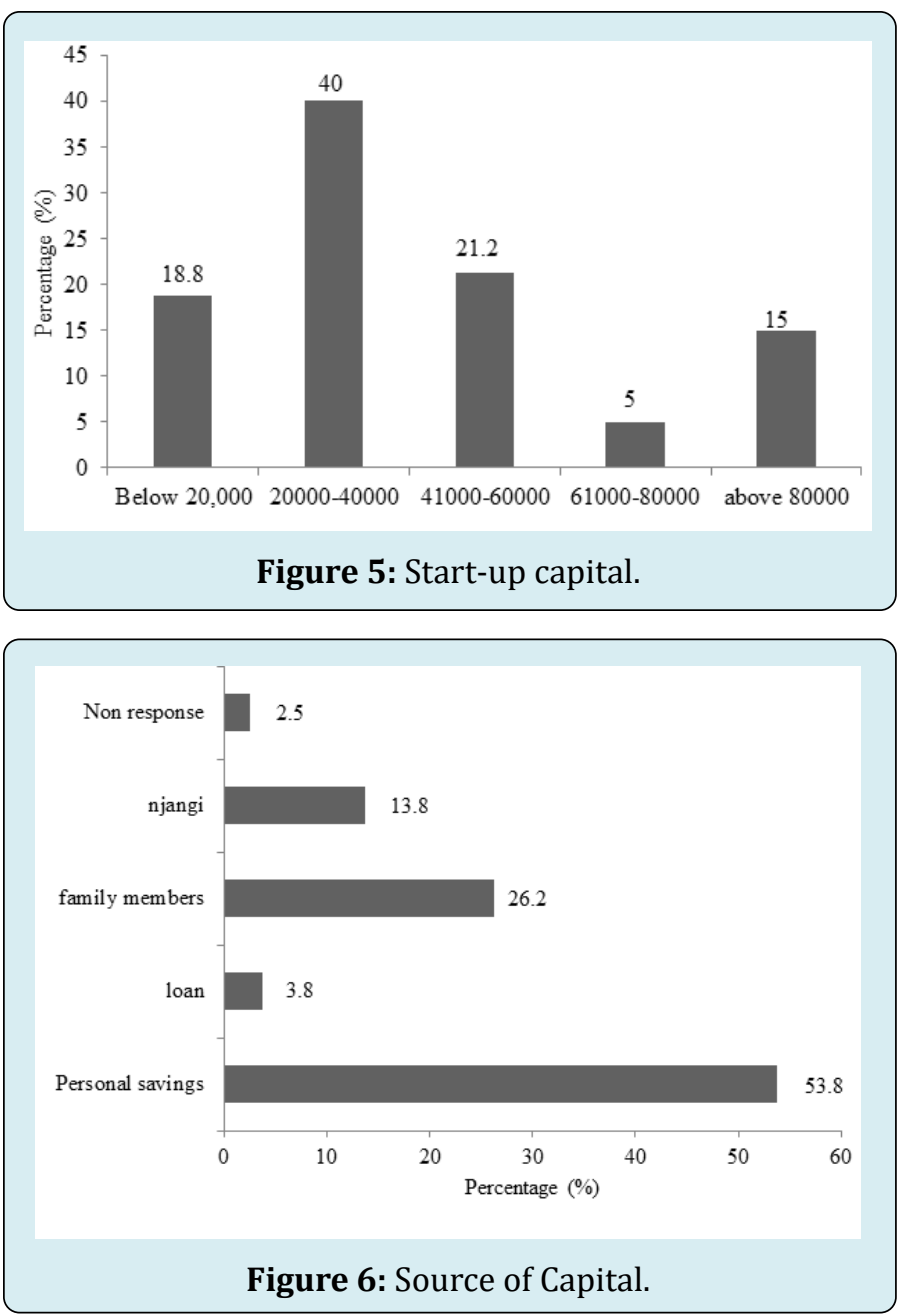
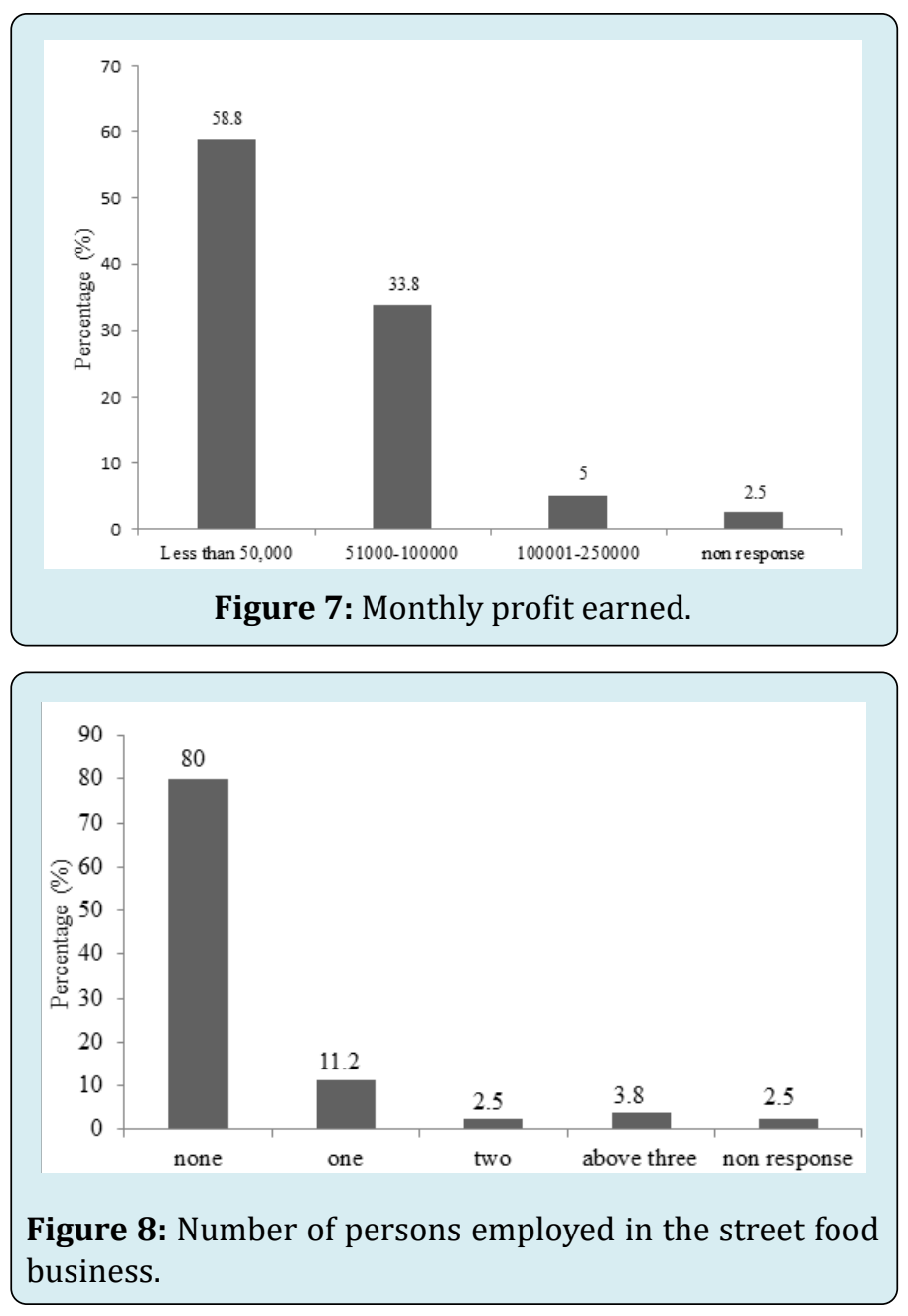

Table 2 and Figure 9 represent the number and main categories of street foods sold respectively in Buea and Kumba. There is a high level of specialization amongst food vendors as most (35\%) prepare only one meal type. Items of street food vending were briefly grouped into few categories (fruits, cooked food, drinks and mixed). Most of the street food vendors in these towns sell cooked foods (76.2\%) compared to fruits and drinks. Figure 10 shows more specifically that, the scope of cooked foods is quite broad with most vendors selling only bolus food (51.2\%), a lesser proportion selling non-bolus foods (11.2\%) while a significant number of the vendors sell both bolus and non-bolus food (30\%). Bolus foods commonly sold in these towns include garri/water fufu and eru, Achu and yellow/black soup (Pepper soup), Fufu corn and hurkle berry. Non bolus foods include rice and soup/stew, beans and plantains, fried puff-puffand beans, and a range of roasted food including roasted beef or pork, roasted fish and, roasted chicken. From Figure 11, it can be seen that majority of the street food vendors, $(61.2 \%)$ used firewood while several others used charcoal $(20 \%)$ to prepare food. This is in line with findings that firewood is the predominant fuel source even though it produces a lot 
of smoke and soot [36]. This reveals a need to improve the energy provision for street vendors given than firewood produces much smoke and other pollutants.

\begin{tabular}{|c|c|c|c|}
\hline & Frequency & Percent & $\begin{array}{c}\text { Cumulative } \\
\text { percentage }\end{array}$ \\
\hline One & 28 & 35 & 35 \\
\hline Two & 14 & 17.5 & 52.5 \\
\hline Three & 13 & 16.3 & 68.8 \\
\hline Four & 10 & 12.5 & 81.3 \\
\hline above four & 14 & 17.5 & 98.8 \\
\hline Non response & 1 & 1.2 & 100 \\
\hline
\end{tabular}

Table 2: Variety of meals prepared in a day.
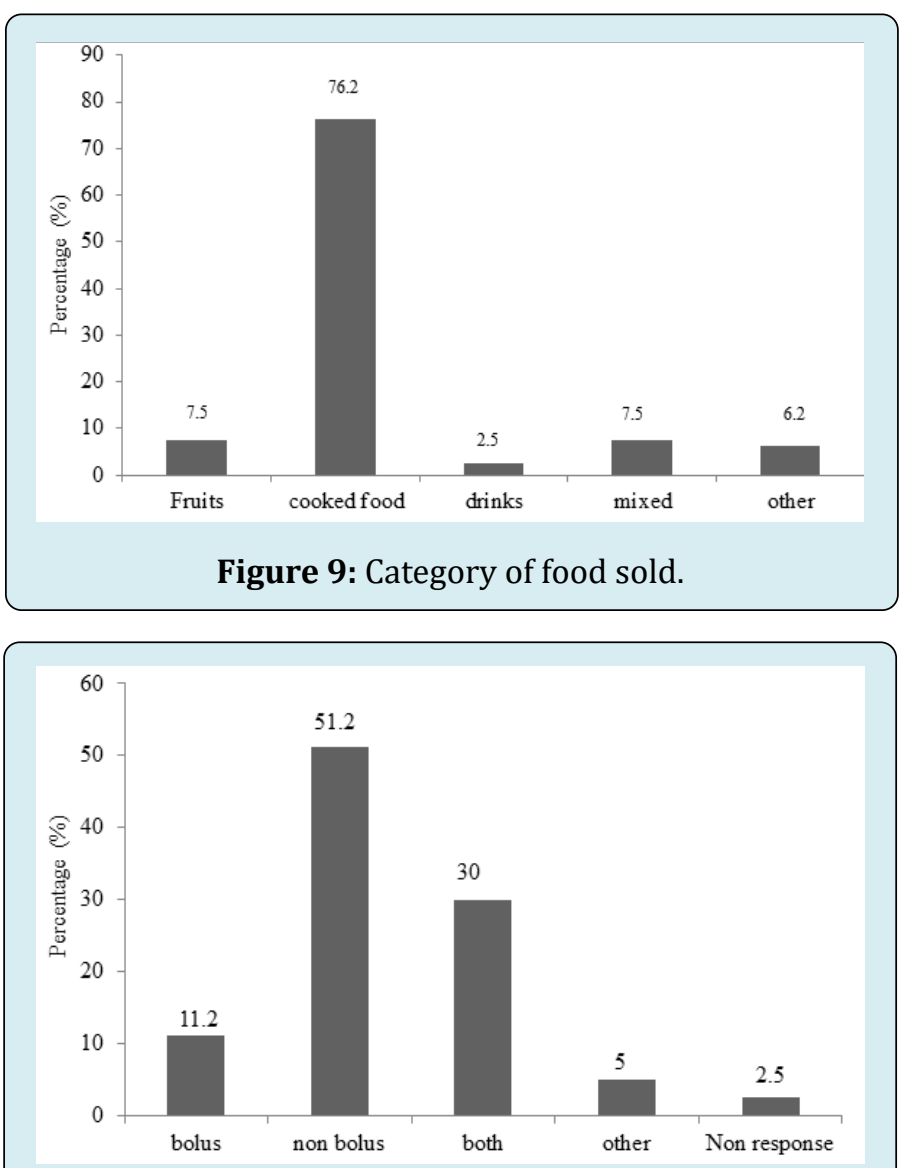

Figure 10: Category of cooked foods sold.

It was observed that most of the vendors surveyed (60\%) had their businesses unregistered (Figure 12) and 25\% of vendors doubted their registration status. This shows lack of government control and puts a doubt to the quality of the foods produced and sold on the street since an unregistered business lacks legal recognition and its activities are void of control by necessary regulatory authorities. Concerning the frequency of receiving training on food preparation and vending (Figure 13 ) reveals that most (82.5\%) of the vendors had never received formal training on running the street food business. They therefore carry out their food processing and distribution based on their local and traditional methods without standard food handling principles making the hygiene and safety of street foods very doubtful. The quality and safety of the foods they sell will therefore be a reflection of their ignorance on food and health issues.
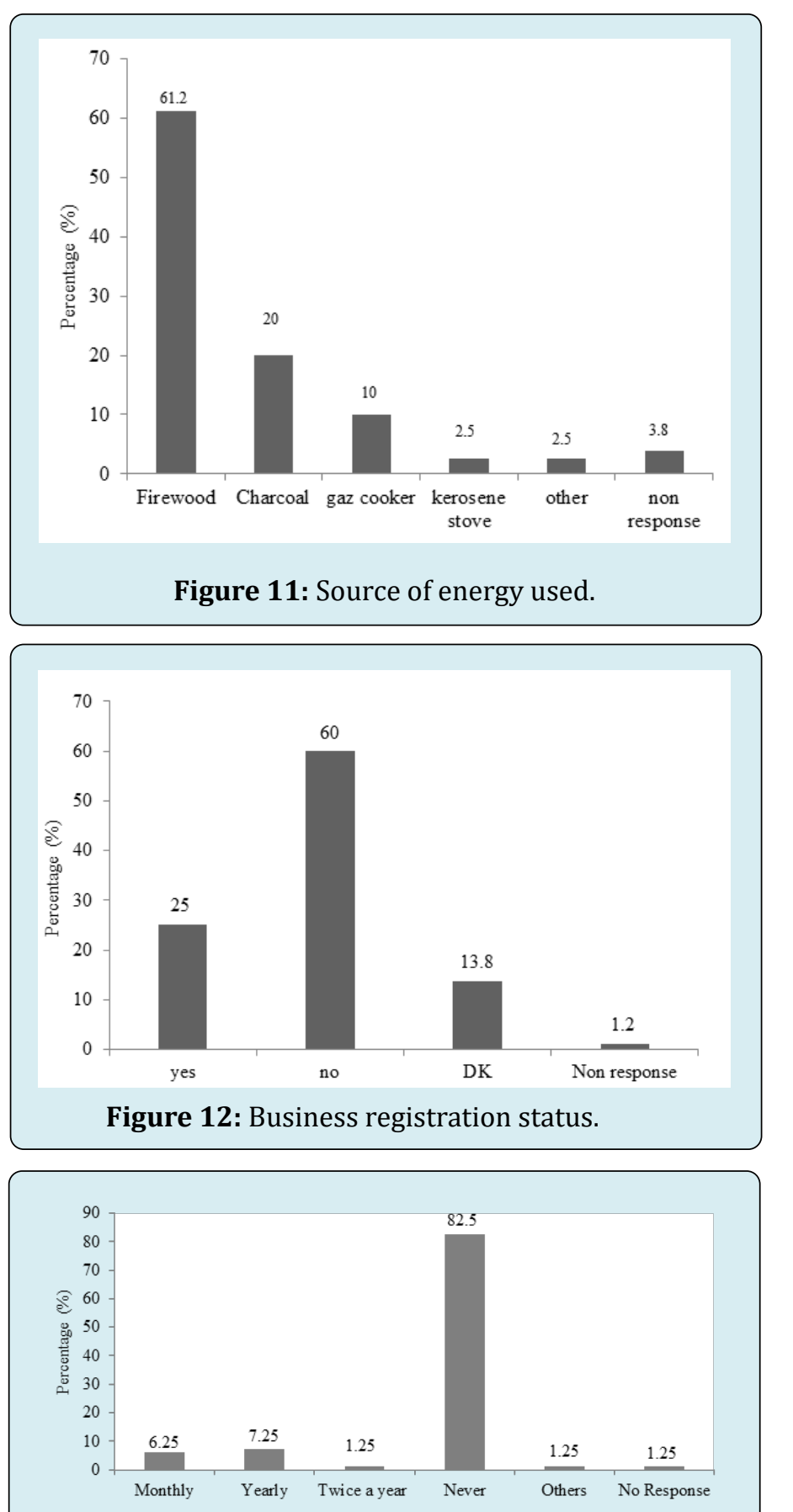

Figure 13: Frequency of training on food preparation and vending. 


\section{Hygienic Conditions of Processing and Distribution of Street Foods}

According to Table 3, most of the vendors (66\%) get their water from the tap while the others get water either from a well $(20 \%)$, rain $(10 \%)$, or stream (4\%). This shows that even though a considerable number of vendors have access to tap water, $44 \%$ prepare food with water from doubtful sources. This percentage is quiet significant considering the that water is a major source of potential contamination of street food but unfortunately many vendors have to use water from wells or streams, or rainwater and even where this water is not contaminated by industrial pollutants, it is often contaminated by faecal microbes. Earlier studies have identified the point of service as the most critical step for potential contamination of street food [37]. The lack of running water or potable water storage makes food safety conditions at these locations untenable, as water is needed for washing food, hands, utensils and equipment and for proper food preparation procedures [38,39].

According to the results, most (46.2\%) of total items sold are completely prepared at home and are sold on the street. Only a few vendors (3.8\%) prepared food both at home and at the vending site while the rest prepared food at the vending site $(26.1 \%)$ or an open space by the road side $(23.8 \%)$. The places were food preparation takes place matters a lot and determines the hygiene and safety of the food especially its exposure to dust, microbes and other pollutants. Tambekar, et al. showed that a good personal hygiene can significantly reduce the level of microbiological contamination of street foods [40]. For foods prepared at home the hygienic conditions under which such foods are processed are not guaranteed and vending sites are neither safe since they are mainly crude structures by the roadside exposed to dust and microbes. This result agree with findings of Cortese et al. that food vendors prepared the foods either at home or at the stalls, usually located by the roadsides which are poorly constructed and cannot give proper protection of the street foods thereby exposing such food to microbial contamination [41]. The hygienic aspects of street food vending as a major concern for food control officers. Vending stands are often crude structures. Running water, washing facilities, and toilettes are often unavailable. This contradicts FAO requirements that foods should be prepared in a place set aside exclusively for that purpose, which should be free from contamination of all types and kept clean at all times. Cortese et al. in a study in Brasil observed that $12 \%$ of the vendors did not provide ice at the point of sale for perishable ingredients; 95\% did not wash hands between food and money transactions and restroom breaks; 91\% did not have hair coverings and $100 \%$ of the vendors did not have access to a water supply [41]. On another hand, Barry reported that accumulated data obtained over the last 20 years on the microbial status and survival of pathogens on coins and currency notes indicates that this could represent a potential cause of sporadic cases of food borne illness [42]. Survival of various microorganisms of concern on money is such that it could serve as a vehicle for transmission of disease and represents an often overlooked enteric disease reservoir.

\begin{tabular}{|c|c|c|c|c|}
\hline \multirow{2}{*}{\multicolumn{2}{|c|}{ Factor Considered }} & \multirow{3}{*}{$\begin{array}{c}\text { Frequency } \\
21\end{array}$} & \multirow{3}{*}{$\begin{array}{c}\text { Percent } \\
26.2 \\
\end{array}$} & \multirow{3}{*}{$\begin{array}{c}\text { Cumulative } \\
\text { Percentage } \\
26.2\end{array}$} \\
\hline & & & & \\
\hline \multirow{4}{*}{ Place of preparation of food } & At the business site & & & \\
\hline & At my place of residence & 37 & 46.2 & 72.4 \\
\hline & In an open space or by the road side & 19 & 23.8 & 96.2 \\
\hline & $\begin{array}{l}\text { Both at home and at the } \\
\text { business site }\end{array}$ & 3 & 3.8 & 100 \\
\hline \multirow{4}{*}{$\begin{array}{l}\text { Source of water used in food } \\
\text { preparation }\end{array}$} & Tap water & 53 & 66 & 66 \\
\hline & Rain & 8 & 10 & 76 \\
\hline & Well & 16 & 20 & 96 \\
\hline & Stream & 3 & 4 & 100 \\
\hline \multirow{4}{*}{ Nearest source of water } & On site & 10 & 12.5 & 12.5 \\
\hline & Less than five minutes' walk & 43 & 53.8 & 63.3 \\
\hline & 5-15 minutes' walk & 13 & 16.2 & 82.5 \\
\hline & More than 15 minutes' walk & 14 & 17.5 & 100 \\
\hline
\end{tabular}

Table 3: Hygienic conditions of processing of street foods. 
The vendors' responses shown in Table 4 reveal that the hygienic condition of distribution of street food is generally unsafe. Our findings reveal that only $2.5 \%$ of the vendors wash and rinse their utensils with warm water and soap for effective cleaning and sterilization. This makes the hygienic condition of not utensils on which the food is served questionable. The table equally shows that most vendors do not have good vending habits especially personal hygiene. According to FAO, street foods are largely unsafe because the vendors are often untrained in food safety, food hygiene and sanitation and most often work in unsanitary conditions [21]. They mostly put on an apron or hair cover only sometimes (24\% and 29\% respectively), while others rarely or never put them on. Never the less putting on jewellery while carrying out their vending business is avoided by most of them (65\%). In addition they do not obligatorily stay away from food preparation when they are sick or having a wound as recommended by WHO as $56.2 \%$ of the respondent's only stay away from food while sick or having a wound sometimes [11]. This attest to reports that street food vendors neglect food safety practices especially personal hygiene, providing to the population unsafe foods [43]. These poor hygiene practices are as a result of total ignorance of many vendors since most have never been trained or due to their low educational background and the lack of control over their activities by the government and local authorities.

\begin{tabular}{|c|c|c|c|c|}
\hline \multicolumn{2}{|c|}{ Factor considered } & \multirow{2}{*}{$\begin{array}{c}\text { Frequency } \\
15 \\
\end{array}$} & \multirow{2}{*}{$\begin{array}{c}\text { Percent } \\
18.8 \\
\end{array}$} & \multirow{2}{*}{$\begin{array}{c}\begin{array}{c}\text { Cumulative } \\
\text { Percentage }\end{array} \\
18.8 \\
\end{array}$} \\
\hline \multirow{6}{*}{$\begin{array}{c}\text { Methods of washing and rinsing of } \\
\text { utensils }\end{array}$} & With cold water & & & \\
\hline & Cold water and soap & 58 & 72.5 & 91.3 \\
\hline & warm water & 1 & 1.2 & 92.5 \\
\hline & With warm water and soap & 2 & 2.5 & 95 \\
\hline & Other & 1 & 1.2 & 96.2 \\
\hline & Non response & 3 & 3.8 & 100 \\
\hline \multirow{6}{*}{$\begin{array}{l}\text { Frequency of changing water used in } \\
\text { washing utensils }\end{array}$} & Once a day & 4 & 5 & 5 \\
\hline & Twice a day & 20 & 25 & 30 \\
\hline & When dirty & 22 & 27.5 & 57.5 \\
\hline & After each cleaning & 25 & 31.2 & 88.7 \\
\hline & Others & 5 & 6.3 & 95 \\
\hline & No response & 4 & 5 & 100 \\
\hline \multirow{5}{*}{ Reasons for changing water } & Dirty appearance & 60 & 75 & 75 \\
\hline & Food particles inside & 8 & 10 & 85 \\
\hline & Long time usage & 4 & 5 & 90 \\
\hline & To please my customers & 5 & 6.2 & 96.2 \\
\hline & No response & 3 & 3.8 & 100 \\
\hline \multirow{4}{*}{ Preservation of leftover food } & In the refrigerator & 18 & 22.5 & 22.5 \\
\hline & $\begin{array}{l}\text { Heat it and preserve for the } \\
\text { next day }\end{array}$ & 12 & 15 & 37.5 \\
\hline & Consume at home & 47 & 58.8 & 93.3 \\
\hline & Throw away & 3 & 3.8 & 100 \\
\hline \multirow{5}{*}{$\begin{array}{l}\text { Aspect of food quality considered most } \\
\text { when selling street food }\end{array}$} & Hygiene (safety) & 44 & 55 & 55 \\
\hline & nutrition (health) & 10 & 12.5 & 67.5 \\
\hline & aesthetic (appearance) & 18 & 22.5 & 90 \\
\hline & function (service) & 7 & 8.8 & 98.8 \\
\hline & Non response & 1 & 1.2 & 100 \\
\hline
\end{tabular}


Food Science \& Nutrition Technology

\begin{tabular}{|c|c|c|c|c|}
\hline \multirow{5}{*}{ Wearing of apron } & Always & 23 & 28.8 & 28.8 \\
\hline & Sometimes & 24 & 30 & 58.8 \\
\hline & Rarely & 16 & 20 & 78.8 \\
\hline & Never & 13 & 16.2 & 95 \\
\hline & Non response & 4 & 5 & 100 \\
\hline \multirow{5}{*}{$\begin{array}{c}\text { Covering of hair during food preparation } \\
\text { and vending }\end{array}$} & Always & 18 & 22.5 & 22.5 \\
\hline & Sometimes & 23 & 28.8 & 51.3 \\
\hline & Rarely & 15 & 18.7 & 70 \\
\hline & Never & 18 & 22.5 & 92.5 \\
\hline & Non response & 6 & 7.5 & 100 \\
\hline \multirow{5}{*}{$\begin{array}{l}\text { Keeping away from food vending when } \\
\text { sick or wounded }\end{array}$} & Always & 15 & 18.8 & 18.8 \\
\hline & Sometimes & 45 & 56.2 & \\
\hline & Rarely & 9 & 11.2 & \\
\hline & Never & 9 & 11.2 & \\
\hline & Non response & 2 & 2.5 & \\
\hline \multirow{5}{*}{$\begin{array}{l}\text { Putting on of arm and hand Jewry while } \\
\text { carrying out vending activities }\end{array}$} & Always & 8 & 10 & \\
\hline & Sometimes & 8 & 10 & \\
\hline & Rarely & 10 & 12.5 & \\
\hline & Never & 52 & 65 & \\
\hline & System & 2 & 2.5 & \\
\hline
\end{tabular}

Table 4: Hygienic conditions of distribution of street foods.

\section{Conclusion}

This study suggests that improvements are needed in food handling education, government regulation and infrastructure for street food vendors. The street food vendors' food handling practices in most cases were below international standards, which are inconsistent. Most of street food vendors were females and had a low educational level. In addition, they did not have any formal training on food safety which contributed to the unsafe (unhygienic) conditions under which the foods were prepared and vended. They had poor personal hygiene practices including lack of aprons and hair cover. In light of the findings of this research, the following specific recommendations can be drawn with a view of improving the hygiene and vending of Street food in Cameroon in general, particularly in the urban centres of Buea and Kumba. The government should recognise street food industry through legislation and introduction of a code of practice for street food vendors. She through her councils should consider the establishment of street food centres with decent shelters which can be rented by street food vendors in order to provide an environment fostering the preparation and serving of safe food. The government and councils should provide essential public utilities such as potable water, garbage collection, public toilets, adequate light, and drainage and solid/water disposal, amongst others. Public awareness for vendors to understand agencies that regulate vending in Cameroon and register for certificate of authority to operate as street entrepreneurs. Neglected aspects of food safety in Cameroon, such as good hand hygiene and cleanliness of kitchen facilities, should be emphasized. Local vendor networks can be an effective point of entry for future food hygiene promotion initiatives.

\section{References}

1. Parminder SD (2015) Street Foods in Punjab, Why it is people's choice (A study of street food vendors/kiosks in Patiala). International Journal in Applied Studies and Production Management 1(4): 67-73.

2. FAO (2007) Promises and Challenges of the informal food sector in developing countries.

3. Anon (1996) World Health Organisation. Essential Safety Requirements for Street-vended Foods (Revised Edition). WHO/FAO Food Safety Unit Division of Food and Nutrition, Geneva. 
4. Mosupye FM, Von Holy A (2000) Microbiological hazard identification and exposure assessment of street food vending in Johannesburg, South Africa. International Journal of Food Microbiology 61(2-3): 137-145.

5. Franklin B, Otilia A, Lorlornyo L (2016) Safety and hygiene status of street vended foods in Ho, Ghana. Journal of Hospitality Management and Tourism 7(2): 25-32.

6. Gitahi MG, Wango J, Njange P (2012) Microbial Safety of Street Food in Industrial Area, Nairobi. Research Journal of Microbiology 7(6): 297-308.

7. Usha R, Vongur, Christoph D (2010) Options to Improve Food Safety in the Street Food Sector of Hyderabad; Analysis on Public Health vs. Sustainability of Livelihood. Research for the Sustainable Development of the Megacities of Tomorrow.

8. Joyce H, Ruivenkamp G, Essegbey G, Frempong G, Jongerden J (2015) Street-Vended Local Food Systems Actors Perceptions on Safety in Urban Ghana: The Case of Hausa Koko, Waakye and GaKenkey. Advances in Applied Sociology 5: 134-145.

9. Ekanem EO (1998) The street food trade in Africa: safety and socio-environmental issues. Food Control 9(4): 211215.

10. FAO/WHO (2005) Practical Actions to Promote Food Safety".Regional Conference on Food Safety for Africa, 3-6 October 2005, Harare, Zimbabwe. Final Report.

11. Acho-chi C (2002) The mobile street food practice in the urban economy of Kumba, Cameroon. Singapore Journal of Tropical Geography 23(2): 131-148.

12. WHO (2005) Informal Food Distribution Sector in Africa (Street foods): Importance and Challenges, pp: 1-10.

13. Assob JCN, Nde PF, Njimoh DL, Nfor O, Njunda AL, et al. (2012) The incidence of foeco-oral parasites in streetfood vendors in Buea, south-west region Cameroon. African Health Sciences 12(3): 376-380.

14. Buliyaminu AA (2016) Risk factors in street food practices in developing countries: A review. Food Science and Human Wellness 5(3): 141-148.

15. Alizon D (1996) Street foods in developing countries: The potential for micronutrient fortification. London School of Hygiene and Tropical Medicine, pp: 66.

16. Mahon BE, Sobel Townes JJM, Mendoza C, Gudiel Lemus M, Cano F, et al. (1999) Surveying Vendors of StreetVended Food: A New Methodology Applied in Two
Guatemalan Cities. Epidemiology and Infection 122(3): 409-416.

17. Ghosh M, Wahi S, Kumar M, Ganguli A (2007) Prevalence of enterotoxigenic Staphylococcus aureus and Shigella spp. in some raw street vended Indian foods. Int J Environ Health Res 17(2): 151-157.

18. DeSousa CP (2008) The impact of food manufacturing practices on food borne diseases. Braz Arch Biol Technol 51(4): 815-823.

19. Steyn NP, Labadarios D, Ne JH (2011) Factors which influence the consumption of street foods and fast foods in South Africa-a national survey. Nutrition Journal 10: 104.

20. Nfor ON (2007) Faecal Oral Parasites in street Food Vendors in the Buea Municipality (S.W Province Cameroon), University of Buea, M.Sc. Thesis, pp: 96.

21. FAO (2009) Good hygienic practices in the preparation and sale of street food in Africa-Tools for training (Roma).

22. FAO (2010) INFOSAN-information note n.3/2010. Safety of street vended food.

23. Tinker I (1993) The street food project: Using Research for Planning. Berkeley Planning Journal 8: 1-20.

24. Sher V (2006) The impact of globalization on the informal sector in Africa, Addis Ababa, United Nations Economic commission for Africa, pp: 26.

25. Minh NP (2017) Food safety knowledge and hygiene practice of street vendors in Mekong River Delta Region. International Journal of Applied Engineering Research 12(24): 15292-15297.

26. FAO (2006) Improving the nutritional quality of street foods to better meet the micronutrient needs of school children in urban areas. Food and Agriculture Organization and Sokoine University.

27. Namugumya BS, Muyanja C (2011) Contribution of street foods to the dietary needs of street food vendors in Kampala, Jinja and Masaka districts, Uganda. Public Health Nutrition 15(8): 1503-1511.

28. Miriam O, Fulton J, Ibro G, Lowenberg-DeBoer J (2011) Women Entrepreneurship in West Africa: The Cowpea Street Food Sector in Niger and Ghana. Journal of Developmental Entrepreneurship 16: 37-63.

29. Isaac M, Dominic A, Wellington O (2013) Hygienic Practices among Food Vendors in Educational Institutions in Ghana: The Case of Konongo. Foods 2(3): 


\section{Food Science \& Nutrition Technology}

282-294.

30. Edima HC, Tem RN, Awono ET, Biloa M, Ndjouenkeu R (2014) Case Study of the Street Food Sector in the Metropolitan Areas of a Cameroonian City, Yaoundé. International Journal of Current Microbiology and Applied Sciences 3(9): 740-751.

31. Manisha C, Lipi BM, Goswami JS, Meenakshi DM (2011) Will capacity building training interventions given to street food vendors give us safer food? A cross-sectional study from India. Food Control 22: 1233-1239.

32. Tavonga N (2014) Operations of street food vendors and their impact on sustainable urban life in high density suburbs of harare, in Zimbabwe. Asian Journal of Economic Modelling 2(1): 18-31.

33. Omemu AM, Aderoju ST (2008) Food safety knowledge and practices of street food vendors in the city of Abeokuta, Nigeria. Food Control 19(4): 396-402.

34. Rheinländer T, Olsen M, Bakang AJ, Takyi H, Konradsen F, et al. (2008) Keeping Up Appearances: Perceptions of Street Food Safety in Urban Kumasi, Ghana. Journal of Urban Health: Bulletin of the New York Academy of Medicine 85(6): 952-954.

35. Fellows P, Hilmi M (2012) Selling street and snack foods, Food and Agriculture Organization of the United Nations, Diversification booklet number 18: 90 .

36. Leonard T, Susil L, Satya RS (2003) Final Project Report, Practical Answers to Poverty. Energy and Street Food,

\section{DFID Kar Project R7663.}

37. Liu Z, Zhang G, Zhang X (2014) Urban street foods in Shijiazhuang city, China: current status, safety practices and risk mitigating strategies. Food Control 41(4): 212218.

38. Rane S (2011) Street vended food in developing world: hazard analyses. Indian Journal of Medical Microbiology 51(1): 100-106.

39. Proietti I, Frazzoli, C, Mantovani A (2014) Identification and management of toxicological hazards of street foods in developing countries. Food and Chemical Toxicology 63: $143-152$.

40. Tambekar DH, Kulkarni RV, Shirsat SD, Bhadange DG (2011) Bacteriological Quality of Street Vended Food Panipuri: A case study of Amravati City (Ms) India. Bioscience Discovery 2(3): 350-354.

41. Cortese RDM, Veiros MB, Feldman C, Cavalli SB (2016) Food safety and hygiene practices of vendors during the chain of street food production in Florianopolis, Brazil: A cross-sectional study. Food Control 62: 178-186.

42. Barry M (2002) Handling money and serving ready-toeat food. Food Service Technology 2: 3 .

43. Kok R, Balkaran R (2014) Street Food Vending and Hygiene Practices and Implications for Consumers. Journal of Economics and Behavioral Studies 6(3): 188193. 